Annals of Warsaw University of Life Sciences - SGGW

Horticulture and Landscape Architecture No 40, 2019: 29-42

(Ann. Warsaw Univ. of Life Sci. - SGGW, Horticult. Landsc. Architect. 40, 2019)

DOI 10.22630/AHLA.2019.40.3

\title{
Selected problems related to the functioning of art installations in the cultural space of Poland - a case study of Zbawiciela square in Warsaw
}

\author{
TOMASZ SAMSEL ${ }^{1}$, MARIUSZ ANTOLAK ${ }^{2}$, JACEK BOROWSKI $^{3}$ \\ ${ }^{1}$ AG-Complex Sp. z o.o. \\ ${ }^{2}$ Faculty of Environmental Management and Agriculture, University of Warmia and Mazury \\ in Olsztyn \\ ${ }^{3}$ Faculty of Civil and Environmental Engineering, Warsaw University of Life Sciences - SGGW
}

\begin{abstract}
Selected problems related to the functioning of art installations in the cultural space of Poland - a case study of Zbawiciela square in Warsaw. The range of research in the publication concerned the problems during the construction process and the functioning of green spaces based on the example of the artistic installation called 'Tęcza' ('Rainbow'). The range of problems has been presented, concerning the construction of all-accessible urban areas. After they have been specified, appropriate solutions have been offered aiming at diminishing or avoiding them. The research has been conducted with use of the survey method among officials, designers and the contractors of urban investments. The most common problems faced by the surveyed groups are: lack of communication between individual participants in the investment as well as lack of social consultations. All the surveyed spoke of formal difficulties. The officials point to negligence on behalf of the designers and contractors. The former, on the other hand, point out to the officials' incompetence and lack of factual preparation. Undoubtedly all participants in the research would like to see the investment process improved and their knowledge on it deepened. All of them emphasize that in the whole "investment triangle" it is the society that is the most important as well as any citizen-user of the public space. It may be concluded that all surveyed participants suggest both: the need of increasing education within the scope examined by the author and ensuring (at municipal level) a coordinator responsible for green investments in a city.
\end{abstract}

Key words: public space, landscape art, LGBT community, artistic installation 'Tęcza', street art, tolerance

\section{INTRODUCTION}

There are certain cities, places and spaces which represent pride, which make us feel proud - or embarrassed. These places are usually subject to extraordinary public interest and involvement; they can be social and cultural centres of gravity, meeting points, symbols of urban prosperity or decline (Dymnicka and Opacki 2003, Szczepański 2003, Lorens and Martyniuk-Pęczek 2010). We could consider these places as everyday locations, or as places we visit as tourists. Lorens wrote that these spaces often encourage reflection, excite emotions or contribute to the mosaic-like representation of our world, as opposed to a monolithic image of the past (Jałowiecki 2003, Lorens and Martyniuk-Pęczek 2010). Artistic installations in cities play a very important part in Poland's contemporary cultural landscape. Considering city dwellers' frantic pace of life, such artistic installations are among the very few opportunities peo- 
ple have to encounter art. These installations are usually transient street furniture items. However, it is not uncommon for some of them to represent much more, and certain locations would be hard to imagine without these installations. Art in the public space can be perceived as a set of potential opportunities for the development of social and cultural capital. An encounter with art will leave a mark on human awareness, even if this kind of experience is not supported by deeper insight. Where such marks on awareness are left, we can speak of the socially, culturally and economically important consequences of encounters with art (Dziadzia 2015). Public spaces in cities have a unique role as outdoor media for exposure to art. They constitute a structure we might call a city's genetic code. Culture is a primary carrier of that code, as it ultimately shapes these public places and gives them their unique character (Bielecki 1996). Popular reception of the presence of art in the public space tends not to be especially complex, while the social capital built by the presence of art can be defined in two ways. Firstly, it involves artistic activity; secondly, it is social involvement.

Based on the example of art installation in Zbawiciela square, in Warsaw entitled 'Tęcza' ('Rainbow'), art in a public space can impact the audience in various ways, particularly in respect of those audience members who do not have sufficient background for perceiving art. The impression on audience members can be positive, but it can also be negative. Dziadzia (2015) notes that observers can perceive such art forms "without any special focus or experience, just contemplating the transient as an experience, let- ting it dissolve in the ocean of situations and impressions. Such an extraordinary art installation as 'Tęcza' is capable of exciting passers-by, getting them out of the somehow boring and repetitive cycle of events".

Schacter (2008) wrote that the analysis concerns "devotional objects". They are parts of a cycle, typical of street art, which is important from the social viewpoint on the development of the sculpture entitled 'Tęcza' in Zbawiciela square, in Warsaw. In our discussion of these "devotional objects", we should emphasize that the above mentioned author did not specifically focus in his work on the insight into street art's ways of exerting influence from the religious perspective. The author pointed out that the phenomenon of such art does not rely on its cultural context or type of subject, but rather on its ability to make things happen in the society. This is determined by such factors as the way in which a specific type of art defines the relationships within a society and the dependencies involved. At this point, social interaction can be identified.

We could claim that 'Tęcza' has become a part of housing district Marszalkowska Dzielnica Mieszkaniowa - MDM built in 1952 (Obarska 2010). It would be reasonable to quote Obarska, who wrote that "MDM was developed as a conglomerate of multiple domains. These include a conservative architectural vision of the city, the Communist ideology, utopian concepts, and civilization projects". The author notes that the construction of MDM was associated with the establishment of a: new social order".

Thus, the questions to be asked here are: whether the construction of 'Tęcza' 
in Zbawiciela square was justified, and whether 'Tęcza' matches the "social order" mentioned by the author. Weren't the vicinity of the Church of the Holiest Savior opposite 'Tęcza', the statue of John Paul II in a niche of one of the MDM's tenement arcades, or the shrines in the adjacent yards (Bogdziewicz 1992) inconsistent with the ideology represented by 'Tęcza', set up as an art installation? At first sight, it seems to be an unconventional combination of street-art with the adjacent religious items. Perhaps it is reasonable to ask whether public spaces in Poland are the right places for presenting such artistic visions as 'Tęcza' in Zbawiciela square. Are the Polish people prepared to perceive controversial works of art, referring to difficult topics, concerning the minorities living here?

In such case, the author of the art installation should answer the question about the right thing to do when art, out of its conventional exhibition framework, fails to gain favourable recognition from the audience. How are the audience supposed to treat an artefact which trespasses the familiar framework of exhibitions, or art galleries? We should be aware of the fact that not every observer is an advanced consumer of art or symbols, yet they all have the right to comment and to express their emotions, both good and bad. This holds particularly true for art in public spaces. This type of art touches the daily lives and common experiences of the people who encounter it on their way, whether they want it or not. At the point of such an encounter, bonds or relationships are formed between them, with more or less involvement. Art affects the local people, as well as tourists or restaurant owners nearby. Can an art installation become a showcase for a city, or a source of benefit? We should also mention the problem of urban space development, based on the example of 'Tęcza' as an art installation.

To have those, and other, questions answered, the author of this publication decided to conduct a survey.

\section{MATERIAL AND METHODS}

The purpose of the survey was to present the functioning and local inhabitants' perceptions of controversial art installations, such as the example of 'Tęcza' in Varsovian Zbawiciela square.

The primary goal of the study was to gather the respondents' opinions regarding the reasons justifying the existence and location of 'Tęcza'. Another objective was to determine the essential aspects of the functioning of this controversial structure in the city, perceived by the society as a LGBT symbol. In addition, certain difficulties were highlighted about the process of preparing and building the work, its reconstruction after the fire, and its ultimate removal from the site.

Two methods were used in the research project. The first method was a survey comprising six questions. The study covered random pedestrians, residents of the area, and customers of the adjacent restaurants and bars. The survey was taken in the vicinity of Zbawiciela square and adjacent locations in Warsaw, from the 22nd to the 23rd of March 2019. On the first day of the project, respondents were surveyed in the evening (from 6:00 to 21:00), when the traffic was quite heavy and the local restaurants were $100 \%$ full. 
Subsequent surveys were carried out on the following day, within two distinct time ranges. The first time range was the morning (from 9:00 to 11:00); then respondents were surveyed around lunch time, from 13:00 to 16:00.

Field survey was preceded by a clarification of its purpose and the intended use of the acquired materials. During the survey process itself, the researcher would read out questions from one through six in the specific sequence, the respondents would reply, and the author of the survey would write down the answers to each question.

The individuals surveyed responded to the brief, concise questions quite eagerly. Typically, a single survey took from two to five minutes to complete. The majority of the respondents (around $80 \%$ ) were aged 20-40. Others were within the 40-70 age group (20\%). A total of 217 persons fully answered all the survey questions. Upon completion, the survey was analysed, summarized and discussed. Some of the respondents were foreign tourists, usually unaware of the history of "the rainbow of Warsaw". A very small group of people refused to take part in the survey or exhibited a homophobic attitude towards the issue of "the rainbow in Zbawiciela square".

Question 1 was the following: "What comes to your mind when you think of 'Tęcza' in Zbawiciela square?'. Question 2: "Should there be such art installations as 'Tęcza' in Poland?". Possible answers: "Yes/No/Not sure". Question 3: "Should 'Tęcza' return to Zbawiciela square?". Answers suggested by the pollsters: "Yes/No/Not sure". Question 4: "Do you think that the location of 'Tęcza' was more attractive for tourists and in a cultural sense while 'Tęcza' was present?". The available answer options were somehow limited, i.e. the respondents were asked to reply on a scale from one to three. Question 5: "Was the installation location appropriate?" Answers suggested by the pollsters: "Yes/No/Unable to say". Final question: "Do you live in Warsaw?". There were only two suggested options: "Yes/No".

Another method was observation and dialog taking place during the preparation, erection and disassembly of the work. There was also an essential interview and long discussion with Julita Wójcik, the author of 'Tęcza', and with Małgorzata Ustymowicz, head of department, representative of the Adam Mickiewicz Institute. Another discussion was held with Agnieszka Tarasiuk, producer of 'Tęcza' on behalf of the above mentioned institute, previously a curator of the 'Flower Power' art project in Wigry.

Intensive motorized and pedestrian traffic was observed during the installation reconstruction and disassembly works, as well as certain unnatural behaviours of the people around the work, who attempted to get under the 'Tęcza'. They were probably both supporters and opponents of the art installation. Some of them expressed their awe and satisfaction with the art installation being rebuilt after the fire. Others believed that the project funded for them by the city authorities was a disgrace, shame and dishonor for the Polish people and for the nearby Church of the Holiest Savior.

The article presents a case study for the art installation 'Tęcza'. Selected topics related to the functioning of the installation in the city public space were discussed, as well as the origin of the 
"dispute that emerged out of a combination of a symbol of the covenant of love and hope with a manifestation of tolerance towards sexual minorities" (Dziadzia 2015).

\section{CASE STUDY}

The 'Tęcza' was an arch-shaped sculpture accessible to the general public, designed as a steel structure spanning $+27 \mathrm{~m}$ across and nearly $10 \mathrm{~m}$ high. More than 22,000 red, orange, yellow, blue and purple artificial flowers were used to indicate the colours and the overall image of a rainbow, as shown on the attached Figures 1 and 2.

Julita Wójcik's installation was intended by the author herself as an open-ended and temporary work. Its duration was extended several times; during that period, the installation provoked discussions or even controversies, and its op-

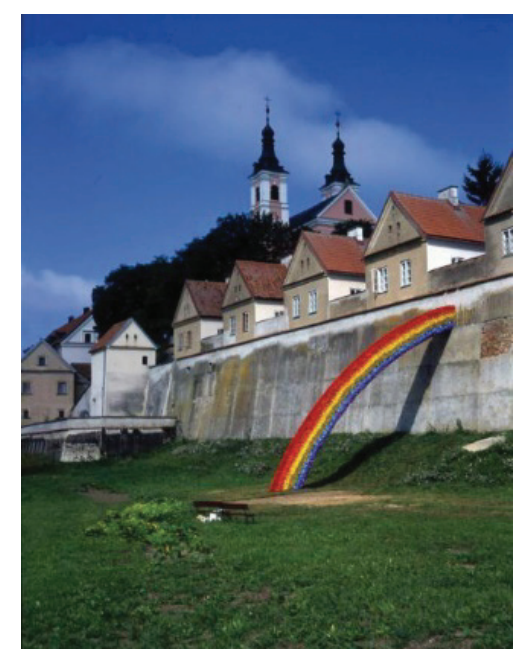

FIGURE 1. 'Tęcza' in the former Camaldolese cloister, in Wigry, 2010

Source: Obieg 2011. Retrieved from: obieg. pl/2011-wydarzenie/20008 [access 25.02.2016].

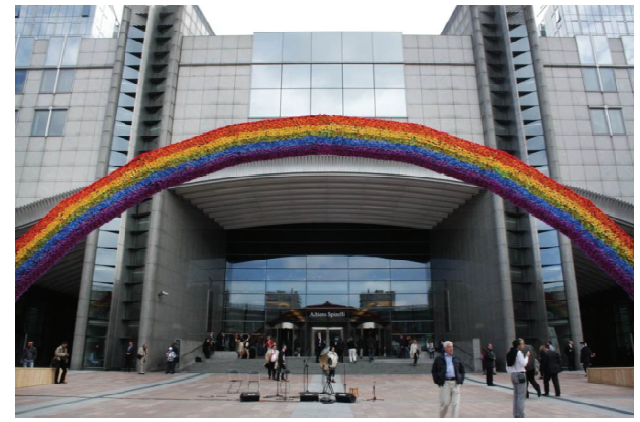

FIGURE 2. 'Tęcza' as 'the bridge between Poland and Belgium", presented in front of the European Parliament, in Brussels, 2011

Source: culture.pl. Retrieved from: http://culture. $\mathrm{pl} / \mathrm{pl} /$ galeria/tecza-julity-wojcik-w-brukseli-galeria [access 25.02.2016].

ponents set it on fire six times (Fig. 3). Members of this social group perceived the rainbow colours as an inappropriate symbol of sexual minorities in the vicinity of a church. Among their reactions were civil unrest and a street rebellion on the 11th of November, when Independence Day is celebrated. The scorched installation was rebuilt afterwards, with the support of its defenders. "What happened around this art installation is not just the discussion about art in the pub-

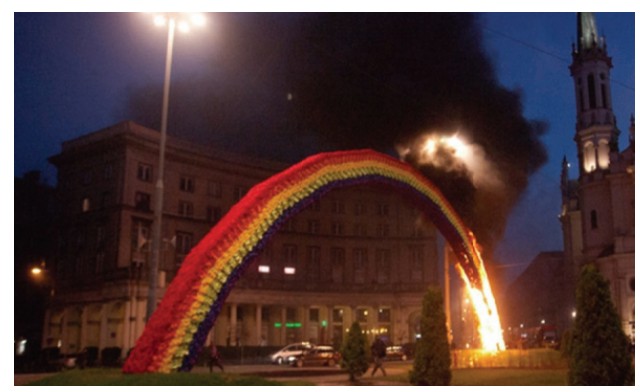

FIGURE 3. 'Tęcza' set on fire during the Independence Day March (photo by R. Kuzm, November 2013)

Source: culture.pl. Retrieved from: http://culture. $\mathrm{pl} / \mathrm{pl} /$ galeria/tecza-julity-wojcik-w-brukseli-galeria [access 25.02.2016]. 
lic space. It's a debate about democracy in Poland" - said Paweł Potoroczyn, director of the Adam Mickiewicz Institute, who also noted that Warsaw after 'Tęcza' was no longer the same city as it had been before.

When 'Tęcza' was first set on fire, he used very strong language in his statement for the press: "Whoever you are, you are a vandal that destroyed an installation by an artist, which had been perfectly synchronized with our city from the first day of its existence. You destroyed a work of art, an artefact that had been making thousands of people smile for nearly half a year, both the people of Warsaw and tourists from all over the world, or even soccer fans" (Dziedzic 2013). This transformation was also the subject of a documentary movie directed by Michał Bielawski (the author of such films as 'Mundial. Gra o wszystko'), parts of which were shot at the 'Saying goodbye to the Rainbow' photographic performance site (Chaciński 2015). The author of 'Tęcza' called her sculpture "simply beautiful" and completely "free", claiming that every viewer could give the installation their own interpretation. The analysis of the press discourse gives rise to the conclusion that the "enthusiasts" would usually associate the presence of 'Tęcza' in the city space with a higher level of acceptance for the emancipation struggle of the LGBT community in Poland. On the other hand, the "opponents" perceived 'Tęcza' as a symbol of an overpowering "European project". When the flowers on 'Tęcza' were burned, its empty, charred frame began to represent more the defeat than the success of Poland's integration with that "European project".
The art installation was repaired (Fig. 4) and rebuilt, yet under a certain pressure (Figs. 5, 6) exerted on the Mayor of Warsaw by some of the local inhabitants, who organized events in defense of 'Tęcza'. Some of these events were called 'Put a Flower into The Rainbow' or 'Unmoved! Kissing under The Rainbow!'. In 2013, right after the in-

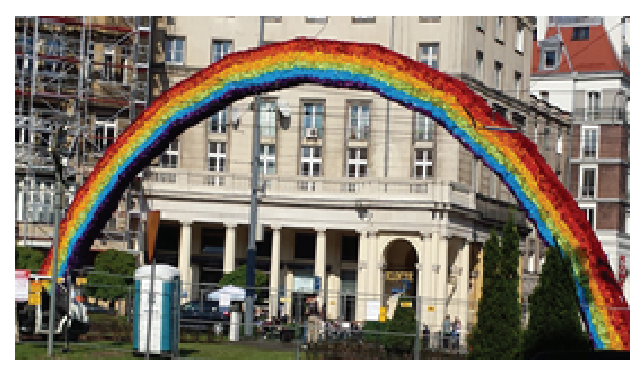

FIGURE 4. 'Tęcza' restored after the fire (photo by T. Samsel, April 2014)

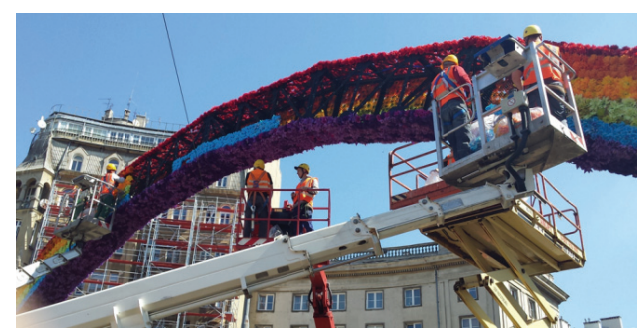

FIGURE 5. The process of the repair of 'Tęcza' after the fire (photo by T. Samsel, April 2014)

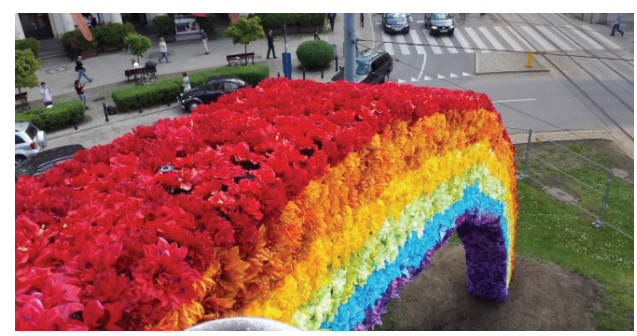

FIGURE 6. Aerial view of 'Tęcza' together with the fire extinguishing system on the day reconstruction was completed after the fire (photo by T. Samsel, April 2014) 
stallation was burned down, the Mayor of Warsaw announced that the sculpture, originally erected as a temporary structure (Culture.pl 2015), would be rebuilt as many times as necessary, as a "symbol of tolerance". She added that it was to become an antagonizing gift, sort of a potlatch, aimed at enhancing the social status.

\section{SELECTED PROBLEMS RELATED TO ART} INSTALLATIONS FUNCTIONING, CONCLUSIONS FROM THE SURVEYS

Many important conclusions should be drawn from the responses given to the survey, to be used as a basis for detailing the problems involved in the existence of controversial art installations in cities.

The analysis of the answers to Question 1 of the survey shows that the respondents most commonly associate 'Tęcza' in Zbawiciela square with: "fighting and aggression"; "LGBT circles"; "joyful colours"; "summer and outdoor cafes's"; "manifestation and setting 'Tęcza' on fire by its opponents and nationalists"; "a controversial installation"; "tolerance and intolerance"; "street art"; "regular lack of available parking places in the vicinity of Zbawiciela square".

Most respondents, i.e. 166 persons (76.5\%), answered "Yes" to Question 2: "Should there be such art installations as 'Tęcza' in Poland?". Forthy respondents (18.43\%) said "No", and only 11 (5.07\%) said they were not sure (Fig. 7).

Most respondents, i.e. 179 persons (83\%), answered "Yes" to Question 3: "Should 'Tęcza' return to Zbawiciela

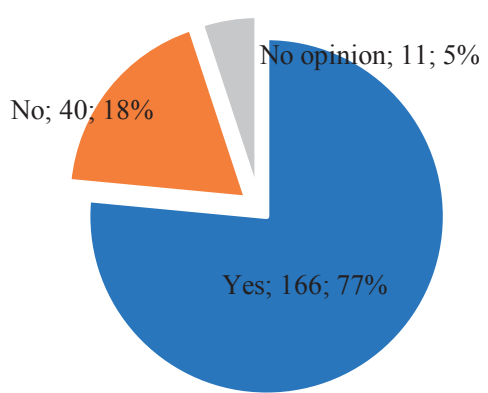

FIGURE 7. Percentages of answers to the question whether such art installations as 'Tęcza' should exist in Poland Source: Own research.

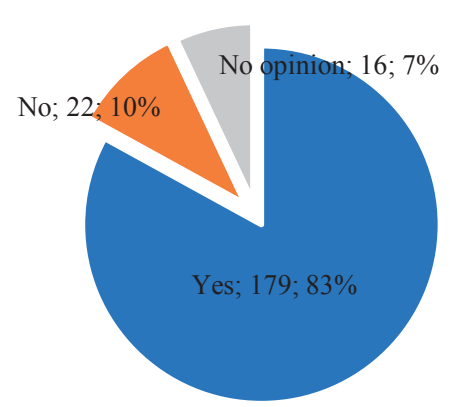

FIGURE 8. Percentages of answers presenting the respondents' opinions on return of 'Tęcza' to Zbawiciela square

Source: Own research.

square?". Only 22 respondents $(10 \%)$ said "No", and there were just 16 (7\%) who were not sure (Fig. 8).

Question 4: "Do you believe that the location of 'Tęcza' used to be more attractive for tourists and in a cultural sense while 'Tęcza' was present?'. As many as 201 respondents $(92.63 \%)$ chose the highest score (3) in their answers. Thirteen respondents $(5.99 \%)$ chose Score 2, and only 3 persons $(1.38 \%)$ chose Score 1 (Fig. 9).

The majority of the respondents (145 persons, or $66.82 \%$ ) answered "appropriate" to Question 5: "Was the installa- 


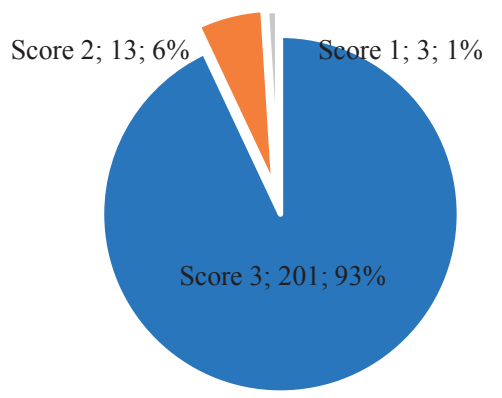

FIGURE 9. Percentages of respondents' answers about their opinion on the tourist and cultural attractiveness of the former location of 'Tęcza' Source: Own research.

tion location appropriate?". The remaining group, i.e. 72 respondents $(33.18 \%)$, replied with a strong "No". Few people said that installations such as 'Tęcza' should be located in museums, while streets or traffic lanes were not the right places for building and presenting sculptures of this type (Fig. 10).

To Question 6, which was the final question, 66 persons (30.42\%) answered that they did not live in Warsaw, and they were just tourists or visitors to their family and friends in Warsaw. The vast majority, 151 respondents $(69.59 \%)$, were inhabitants of Warsaw.

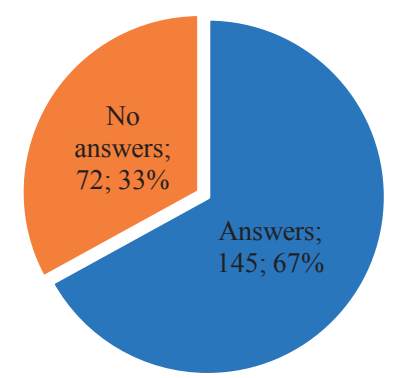

FIGURE 10. Percentages of respondents' answers about their opinion on the appropriateness of the selection of a location for 'Tęcza' Source: Own research.

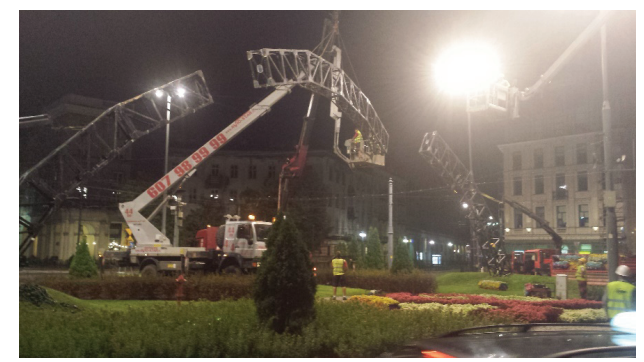

FIGURE 11. Disassembly of 'Tęcza' (photo by T. Samsel, August 2015)

One conclusion that can be drawn from the observations of the public in 2014, while assembly and disassembly work was being carried out (Fig. 11) is that the established 'Tęcza' in Zbawiciela square revealed a conflict, instead of embodying harmony and satisfaction. The conflict affected diverse communities, and at the same time demonstrated the dispute about the sculpture. In addition, a question emerges of whether various groups in society are capable of peaceful coexistence in the same areas, without a risk of exclusion. Apart from the social problems and the issues involved in the functioning of this art installation, certain other issues emerged with its original erection on 8 June 2012, its restoration after the fire on 24 April 2014, and its disassembly on 26 August 2015.

Another important issue that occurred during the construction of the 'Tęcza' were the formal procedures. A number of difficult formal issues needed to be resolved in a short time in order to remove the art installation from the so-called road lane. There were complicated official procedures involved, as well as long queuing times for the issue of relevant authorizations and administrative decisions. The contracting authority only envisaged five days for handling the 
formal requirements, and just four hours for disassembling the 'Tęcza'.

Certain social problems could also be observed during the construction and disassembly process (Fig. 12). These included aggressive and hostile attitudes among a certain group of society, incited by the attempt at rebuilding the installation after the fire. The builders involved in the construction process of 'Tęcza' were subjected to insults hurled by the opponents of the installation.

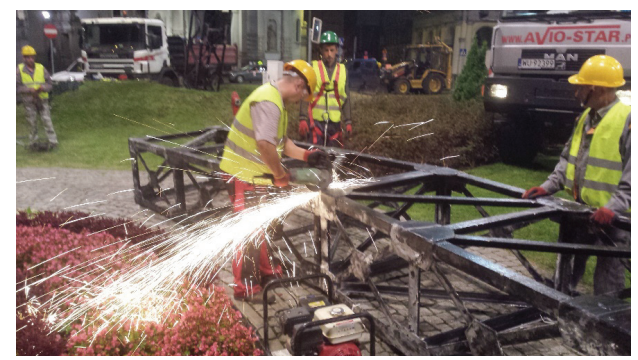

FIGURE 12. 'Tęcza' being prepared for transport immediately after disassembly (photo by T. Samsel, August 2015)

Another issue was the "feeling of agitation" among the supporters and opponents of 'Tęcza' at the time of disassembly. A crowd of several thousand people who were present on the disassembly site, along with TV coverage and interviews, exerted more pressure on the people disassembling the sculpture.

\section{SUMMARY AND DISCUSSION}

The survey aimed at discovering the associations the public had with "the rainbow of Warsaw" and its impact on the local community. Moreover, an attempt was taken at verifying whether the art installation under consideration was indeed a unique "public space phenomenon", or perhaps an "art object", or a symbol of the LGBT community.

Here, we need to emphasize the importance of the local communities and the general public in the process of creation of art installations in the cultural space of Poland. The author of this publication notes that dissatisfaction could be observed in certain groups of the society from 2012, when 'Tęcza' was originally built, until 2015 when it was disassembled. There were several attempts at setting the installation on fire, as a demonstration of opposition, ultimately leading to the complete burning of the artefact.

To a certain extent, the study conducted in 2019 showcases a change in public attitudes towards art installations of this type in cities. Furthermore, research shows that a large majority of respondents believe that installations such as 'Tęcza' should exist elsewhere in Poland, as well.

Despite the absence of 'Tęcza' in Zbawiciela square since 2015, it is remembered quite well by a large majority of the public. It is still associated with the LGBT community, with controversy, love, tolerance or lack thereof, protests, and regular arson attempts. Some respondents mentioned they remembered 'Tęcza' as an installation generating "media buzz". Others likened the sculpture with "beauty", and only a small group perceived it as "kitsch". It should be strongly concluded from the survey of 217 respondents that a clear majority would like 'Tęcza' to return to Zbawiciela square. Thus, one may say that the Polish people exhibit a desire to encounter unusual, original street art installations. In addition, 201 out of the 217 respondents said that the Mokotów 
district of Warsaw had been more attractive for tourists while 'Tęcza' existed there. Nearby restaurants were busier while the sculpture was there. Despite the specificity of the location, near a church, a statue of John Paul II and numerous shrines, a large majority of the respondents considered this place to be appropriate for this type of exhibition. Some people believed that such controversial works as "the rainbow of Warsaw" should not be erected at a roundabout. The respondents' familiarity with the installation in question is supported by the fact that the largest group of them said they lived in Warsaw. There were only 66 people residing outside Warsaw.

The analysis of the study results leads to the conclusion that the sculpture was ultimately accepted by a significant number of inhabitants of the city. Consequently, the level of tolerance of the LGBT community in Poland appears to be significantly higher than that observed during 2012-2015. At the moment, both the local people and tourists/visitors identify certain selected locations with art installations. It should be added here that after a certain time, the public gets accustomed to controversial installa- tions or extraordinary street art items. Moreover, it needs to be emphasized that most people tend to call such spaces their "favourites" in hindsight, and expressly communicate their "longing" for such artefacts after they are disassembled. Analysis of the statistical studies demonstrates a clearly higher percentage of positive answers, which is statistically significant (the table).

Destroying 'Tęcza' can be confronted with the another quote from Schacter, already quoted. This author, in his analysis of London's street art and installations built using this formula, believes that this type of roadside art is always at risk of being destroyed, and is somehow doomed for destruction. The regular arson attempts targeted at sculpture in Zbawiciela square can also be referenced to Latour (2010), stating that street art is a space of uncertainty and doubt, where you can observe a "war of images". A similar uncertainty regarding the existence of 'Tęcza', the phenomenon of destruction and war could be noticed while 'Tęcza' persisted on Varsovian Zbawiciela square. Certain social groups and local people expressed their opposition through negative comments

TABLE. Statistical analysis of randomness of the replies

\begin{tabular}{|c|c|c|c|c|c|}
\hline \multirow{2}{*}{ Question } & \multicolumn{3}{|c|}{ Answer } & \multirow{2}{*}{ p-Value } & \multirow{2}{*}{ Significance } \\
\cline { 2 - 5 } & yes & no & don't know & & no \\
\hline 1 & 123 & 94 & - & 0.1438 & yes \\
\hline 2 & 166 & 40 & 11 & 0.0000 & yes \\
\hline 3 & 179 & 22 & 16 & 0.0000 & yes \\
\hline 4 & 201 & 13 & 3 & 0.0000 & yes \\
\hline 5 & 145 & 72 & - & 0.0003 & yes \\
\hline 6 & 151 & 66 & - & 0.0001 & \\
\hline
\end{tabular}

Source: Own research. 
on the Internet and through six attempts at burning the flowers installed within the arch-shaped structural frame. Particular hostility and defiance could be observed when the artefact was completely burned down during a street march of the Młodzież Wszechpolska (All-Polish Youth organisation) on 11 November 2013. On the other side, there is a notable group of supporters of the installations and successful attempts at reconstruction. With the strong position expressed by the capital's authorities, evident support and pressure exerted by the defenders of street art, it became possible for 'Tęcza' to "take to the street" again. As Witosz (2010) notes in her publication, it was not the "aesthetic qualification" that formed the core of the fierce conflict, but rather the symbolic value of the work. In addition to the associations 'Tęcza' has with the emancipation of the LGBT community, it should also be recognised and perceived from the perspective of "love, hope, reconciliation, respect for human dignity, and the right to have one's views and beliefs respected". Witosz clearly emphasises that street art installations such as 'Tęcza' should not be "a symbol of the division of Polish society, a monument of sexual deviation, anomaly, or references to a queer rainbow". Other researchers, such as Dubisz (2003) - recognised for his critical analysis approach - warn of fallacious reasoning. Other authors who speak of tolerance are Czyżewski et al. (1997). These authors claim that while so-called common space or mediatisation areas are lacking in the public space, their clashes increase the tension, which is defined in literature as "ritual chaos". Based on the analysis of other authors' research and publications, we should conclude that the conflict around 'Tęcza' in Zbawiciela square is an example of an ideological shift worldwide. The changes that are taking place can be compared to the process of discourse crossing, and discourses as such can be considered mutually exclusive. Such concepts as exclusion, discrimination or tolerance are relative. As an example, we may refer to comments published on the Internet, where their authors accuse the LGBT community of "taking over the public space". Ignerska (2014) opines that Julita Wójcik's work was well integrated in the city space, and its shape emphasised the arcade arches and the circular line of buildings around Zbawiciela square. On the other hand, the authors of 'Zrób to w Warszawie!', an alternative city guide, call the installation, which was being regularly destroyed and rebuilt, a symbol of tolerance and openness, concluding that it "triggers an enormous load of extreme emotions which can no longer be restrained" (Kowalska and Kamiński 2014). Journal Polityka Weekly gave the author its Passport award in the field of visual art for 'Tęcza' design; on the other hand, a certain councillor of Warsaw noted that the sculpture was concealing one of the most beautiful churches in Warsaw, demanding that it be moved to a more "contemporary location" (Dziedzic 2013).

To minimize the problems encountered during the process of construction and disassembly of the installation, a competent institution should be established in the city, or a new function should be appointed, responsible for project creation and review. This role would understand the investment process and participate in the project advance- 
ment, from the time of preparation of the project dossier until the completion of project execution. In order to facilitate and streamline the city's handling of the formal requirements, it is considered reasonable for the municipal authorities to hire a consultancy firm. The task force dedicated to this purpose would prepare training courses for existing and new municipal office staff. Furthermore, it seems necessary to provide training for a specific group of personnel in the field of knowledge of the municipal structure and competence ranges.

\section{CONCLUSIONS}

'Tęcza' in Zbawiciela square, in Warsaw triggered very strong emotions in people. Its opponents mentioned the alleged takeover of the public space by LGBT communities. Its promoters accused the opponents of extreme intolerance.

The cultural and symbolic connotations of 'Tęcza' turned out to be definitely more important for its evaluation than the aesthetic quality, which was due to the context of the location and the message carried by the street-art installation itself.

These strong emotions were expressed as comments on social media. Extremely negative emotions manifested through repeated setting of the installation on fire. Positive emotions were expressed through the supporters' actions aimed at restoration. These emotions were also perceived by workers involved in the assembly and reconstruction of 'Tęcza'.

The attitudes of the people of Warsaw evolved with time; at the moment, the majority of the survey respondents would accept the installation, which no longer exists. This is an indication of a change that is taking place in the realm of community awareness.

In making decisions concerning locations of potentially controversial street art artefacts, the cultural context of the place should be carefully considered, so as to avoid or even to mitigate social conflicts.

\section{REFERENCES}

BIELECKI C. 1996: Gra w miasto [City game]. Fundacja Dom Dostępny, Warszawa.

BOHDZIEWICZ A. 1992: O kapliczkach [About chapels]. Konteksty. Polska Sztuka Ludowa 46 (3-4): 201-204.

CHACIŃSKI B. 2015: Już dzisiaj rozpocznie się demontaż tęczy z placu Zbawiciela [The dismantling of the rainbow from Zbawiciel square will start today]. Retrieved from: https://www.polityka.pl/tygodnikpolityka/ kraj/1630995,1,juz-dzisiaj-rozpocznie-siedemontaz-teczy-z-placuzbawiciela.read?page $=144 \&$ moduleId $=4677$ [access 12.11.2018].

Culture.pl 2015: Saying Goodbye To The Rainbow. Retrieved from: http://culture.pl/en/article/saying-goodbye-to-the-rainbow [access 12.11.2018].

CZYŻEWSKI M., KOWALSKI S., PIOTROWSKI A. 1997: Rytualny chaos. Studium dyskursu publicznego [Ritual chaos. A study of public discourse]. Wydawnictwo Aureus, Kraków.

DUBISZ S. (Ed.) 2003: Uniwersalny słownik języka polskiego [Universal Polish language dictionary]. Wydawnictwo Naukowe PWN, Warszawa.

DYMNICKA M., OPACKI Z. (Eds.) 2003: Tożsamość miejsca i ludzi. Gdańszczanie i ich miasto $\mathrm{w}$ perspektywie historyczno-socjologicznej [Place and people identity. Gdańsk residents and their city from a historical and sociological perspective]. Oficyna Naukowa, Warszawa. 
DZIADZIA B. 2015: Kiedy sztuka wytwarza kapitał. Zaangażowanie i sztuka w przestrzeni publicznej [When art creates capital. Engagement and art in public space]. In: B. Dziadzia, B. Głyda-Żydek, S. Piskorek-Oczko (Eds.), Sztuka w przestrzeni publicznej. Artystyczne wymiary wytwarzania kapitału społecznego i kulturowego. Fundacja Animacji Społeczno-Kulturalnej, Bielsko-Biała - Cieszyn: 15-30.

DZIEDZIC B. 2013: Fenomen ,placyku” nie przemija. Plac Zbawiciela wciąż modny [The phenomenon of "square" does not go away. Zbawiciela square is still fashionable]. Retrieved from: http://www.warszawa.naszemiasto. $\mathrm{pl} /$ artykul/fenomen-quotplacykuquot-nieprzemija-plac-zbawiciela-wciaz,1858186,artgal,t,id,tm.html [access 12.11.2018].

IGNERSKA M. 2014: Ogarnij miasto. Miejski przewodnik subiektywny [Embrace the city. Subjective urban guide]. Warszawa.

JAŁOWIECKI B. 2003: Tożsamość ludzi, tożsamość miejsc [Identity of people, identity of places]. In: M. Dymnicka, Z. Opacki (Eds.), Tożsamość miejsca i ludzi. Oficyna Naukowa, Warszawa.

KOWALSKA A., KAMIŃSKI Ł. 2014: Zrób to w Warszawie! Alternatywny przewodnik [Do it in Warsaw! Alternative guide]. Biblioteka Gazety Wyborczej, Warszawa.

LATOUR B. 2010: What is iconoclash? Or is there a world beyond the image wars? In: B. Latour, On the modern cult of the factish gods. Duke University Press, Durham - London: 67-97.

LORENS P., MARTNIUK-PECZZEK J. 2010: Problemy kształtowania przestrzeni publicznych [Problems of shaping public spaces]. Wydawnictwo Urbanista, Gdańsk.

Niewzruszeni! Całujmy się pod tęczą! [Unmoved! Kissing under the rainbow]. Post Facebook. Retrieved from: https:/www.facebook.com/ events/572198816186628 [access 20.05.2015].

OBARSKA M. 2010: MDM. Między utopią a codziennością[MDM. Between utopia and everyday life]. Mazowiecka Akademia Książki. Egros, Warszawa.

SCHACTER R. 2008: An ethnography of iconoclash. An investigation into the production, consumption and destruction of street-art in London. J. Mat. Cult. 13 (1): 35-61.
SZCZEPAŃSKI M.S. 2003: Podróże po mniejszym niebie. Ojczyzna prywatna w oglądzie socjologicznym [Traveling in a smaller sky. Private homeland in sociological survey]. Wydawnictwo Urbanista, Gdańsk.

Wetknij kwiatek w tęczę [Put a Flower into The Rainbow]. Post Facebook. Retrieved from: https:/www.facebook.com/wetknijkwiatekwtecze [access 10.10.2017].

WITOSZ B. 2014: O ideologizacji przekonań i postaw estetycznych (wokół publicznego sporu na temat artystycznej instalacji „Tęcza” na placu Zbawiciela w Warszawie) [On ideologisation of beliefs and aesthetic attitudes (around the public dispute about the artistic installation of "Rainbow" in Zbawiciel square in Warsaw)]. Forum Lingwistyczne 1: 27-35.

Streszczenie: Wybrane problemy dotyczace funkcjonowania instalacji artystycznej w przestrzeni kulturalnej w Polsce - studium przypadku placu Zbawiciela $w$ Warszawie. W publikacji zakres badań dotyczył problemów podczas wykonywania i funkcjonowania terenów zieleni na przykładzie instalacji artystycznej „Tęcza”. Przedstawiono zakres zbadanych problemów podczas budowy ogólnodostępnych terenów miejskich. Po ich wyszczególnieniu zaproponowano stosowne rozwiązania celem ich zmniejszenia lub zapobiegania. Badania przeprowadzone były na podstawie metody ankietowej wśród urzędników, projektantów oraz wykonawców miejskich inwestycji. Oprócz badań autorzy wykorzystali wiedzę własną i wieloletnie doświadczenie zawodowe w zakresie budowy przestrzeni publicznych. Problemy, z jakimi najczęściej spotykają się badane grupy, to przede wszystkim brak dialogu między poszczególnymi uczestnikami inwestycji i konsultacji ze społeczeństwem. Wszyscy badani jednoznacznie mówili o trudnościach formalnych i zbyt długich terminach ich załatwiania. Urzędnicy wskazują na zaniedbania ze strony projektantów i wykonawców, na co ci ostatni zwrócili uwagę na niekompetencje urzędników i brak u nich merytorycznego przygotowania. Bez wątpliwości wszystkie badane grupy wyrażają chęć poprawienia procesu inwestycyjnego oraz pogłębiania wiedzy z tego zakresu. Zaznaczają równocześnie, że w całym ,trójkącie inwestycyjnym” najważniejsze są społeczeństwo i każdy obywatel ko- 
rzystający z przestrzeni publicznej. Niewątpliwie można ocenić, że wszyscy ankietowani sugerują zwiększenie edukacji w badanym przez autorów zakresie oraz zapewnienie na szczeblu samorządowym koordynatora do spraw prowadzenia inwestycji miejskich terenów zieleni.

Słowa kluczowe: miejska przestrzeń publiczna, społeczność LGBT, instalacja artystyczna „Tęcza", street art, tolerancja

$M S$ received: 15.11 .2018

MS accepted: 04.12.2019

\section{Authors' address:}

Tomasz Samsel

(https://orcid.org/0000-0001-6412-6356)

AG-Complex Sp. z o.o.

ul. Płytowa 14, 03-046 Warszawa

Poland

e-mail: tomasz.samsel@ag-complex.com.pl
Mariusz Antolak

(https://orcid.org/0000-0003-2436-6990)

Katedra Architektury Krajobrazu

Wydział Kształtowania Środowiska i Rolnictwa Uniwersytet Warmińsko-Mazurski w Olsztynie ul. Prawocheńskiego 17, 10-727 Olsztyn Poland

e-mail: mariusz.antolak@uwm.edu.pl

Jacek Borowski

(https://orcid.org/0000-0003-0656-8724)

Katedra Ochrony Środowiska

Wydział Budownictwa i Inżynierii Środowiska

Szkoła Główna Gospodarstwa Wiejskiego

w Warszawie

ul. Nowoursynowska 166, 02-787 Warszawa

Poland

e-mail: jacek_borowski@sggw.pl 